\title{
Considerações
}

\section{extemporâneas sobre \\ o Manifesto Comunista}

WOLFGANG FRITZ HAUG

T a SITUAÇão PÓs-COMUNISTA, nada parece mais irreal do que a divisa ao 1 final do Manifesto Comunista: "Proletários de todas as naçōes, uni-vos!" Por outro lado, no que concerne ao capitalismo, alguns dos principais prognósticos foram cumpridos de maneira incontestável: sua expansão "por todo o globo terrestre" é a ordem do dia com o nome de globalização; o fato de "a produção e o consumo de todos os países estarem configurados de maneira cosmopolita" salta aos olhos de todo viajante; o desenvolvimento das forças produtivas é de tirar o fôlego; a atual população mundial está bastante familiarizada com "o abalo ininterrupto de todas as situaçōes sociais", com sua "insegurança e movimentação eternas". A difícil crise econômica que atinge e talvez não pare de afligir tão cedo o Japão - até ontem precursor do capitalismo bigh-tech - e os tigres asiáticos - há pouco tempo ainda alunos exemplares do turbocapitalismo - reiterou a credibilidade da tese do Manifesto a respeito da crise: sociedades inteiras encontram-se "remetidas subitamente a um estado de momentânea barbárie", devido a crises econômicas periódicas. E o fato de a burguesia assemelhar-se ao "feiticeiro que já não consegue mais dominar os poderes subterrâneos que invocou" paira como uma escrita no horizonte desse fin de siècle.

Em contrapartida, os horizontes temporais desses prognósticos mostram-se curiosamente desfigurados e irrealistas. $O$ que hoje é confirmado pela visão, na Europa das diligências e da iluminação a querosene - sem dúvida também das primeiras vias férreas - deve ter atuado nos manuscritos como ficção científica, uma vez que a realidade local e global estava muito distante da imagem esboçada atualmente. Numa retrospectiva, o que parece ainda mais singular é o fato de os prognósticos não se apresentarem como tais, mas na forma como o caso é descrito. É preciso refletir a respeito da fausse évidence, que para os autores parece ter contido esse qüiproquó epistemológico. Em geral, o Manifesto erra em todos os pontos em que parece prometer garantias 
histórico-filośfficas para o desfecho de tais lutas, reduzindo economicamente o substrato histórico.

Depois de uma geração, quando o pequeno texto desencadeou seu imenso efeito, o Manifesto foi lido por seus adeptos, na maioria das vezes, à luz dessas falsas evidências: a burguesia teve uma história que naquele momento, porém, chegava ao fim; foi ela quem desenvolveu as forças produtivas, no entanto, já estava atingindo a podridão. Paradoxalmente, no interior das sociedades capitalistas atuavam o movimento operário e, em seguida, sobretudo o antagonismo exterior do sistema, sob forma de países socialistas e estatais, como um estímulo para a formação de instituições e políticas de integração social, e até mesmo para o desenvolvimento das forças produtivas. $O$ marxismo, praticamente concretizado, agia como um "médico junto ao leito do capitalismo doente".

O fato de o Manifesto estar correto, ao contrário da impressão superficial, foi uma surpresa para os "real-socialistas", cujas estruturas de administração imperiosa mostravam-se produtivas, à medida em que o assunto tratasse da construção de uma sociedade industrial de tipo fordista-estatal em Estado de exceçáo. O conceito de "economia planificada" ocultava que aquilo que estava nomeando como tal não era simplesmente uma planificação social, mas sobretudo uma separação do trabalho mental e braçal levada ao extremo, na forma de uma ditadura estatal imposta à sociedade, como consta dos conceitos não menos problemáticos de Marx: o fordismo estatal exigia um desligamento radical do trabalho dispositivo e executivo, sob condiçóes de uma produçáo em massa padronizada e simbolizada pela linha de montagem. Com o enfraquecimento considerável dos agentes in loco na separação simultânea do salário e da produção real, esse sistema provocou uma verdadeira "dissolução do fator subjetivo" (Butenko) que, sob forma de irresponsabilidade organizada beirando o trabalho aparente, assumiu formas venenosas. Em contrapartida, isso fez da organização de responsabilidade, calcada na divisão do trabalho, um ramo particular da polícia secreta, com um regime rigoroso de fiscalização interna. $O$ modo de produçáo e o regime de segurança estatais atuavam finalmente como barreiras intransponíveis na tentativa discutida durante décadas de passar para a reprodução intensiva ou até para a automaçáo e, no conjunto, para o modo de produçáo vinculado à tecnologia de ponta, que contava com o trabalho de responsabilidade individual e, no limite, dispositivo.

No entanto, devido a esses antagonistas orientais, o Ocidente viu-se forçado a estabelecer uma unidade interna (de integraçáo social) e externa (militar e econômica); além disso, a Guerra Fria dos dois sistemas legitimou o uso de 
somas astronômicas para a tecnologia militar. Desse modo era possível contornar a barreira que a propriedade privada burguesa de meios de produçáo representava para o desenvolvimento das forças produtivas. Hoje, o spin-off da pesquisa de tecnologia militar, financiada pelo Estado, define nosso cotidiano, desde a frigideira Teflon até o PC. No entanto, o fato de a antiga Uniăo Soviética ter se separado do círculo dos agentes históricos não contradiz o Manifesto. Se o faz, segue os princípios populares e incansavelmente alimentados por políticos e pelos meios de comunicaçáo de massa de difamar o projeto de um internacionalismo proletário especialmente aos olhos dos trabalhadores, principal público-alvo. Quanto menos política for a formação de um indivíduo e quanto mais ele se movimentar de maneira irrefletida e anistórica pela história contemporânea, mais tenderá a considerar a estrutura de dominação estalinista e seu fracasso definitivo como a contestaçáo de Marx e a morte do projeto socialista.

A irrealidade momentânea presente no internacionalismo dos trabalhadores assalariados modernos, esboçado no Manifesto, salta aos olhos. Por outro lado, ela pode ofuscar como falsa evidência de nossa época pós-comunista. Basta observar a visão de mundo de um ilustre poeta espanhol contemporâneo. Para José Angel Valente, a ameaça foi substituída pelas ideologias totalitárias com o "fantasma da globalização" (el espectro de la mundialización). Ele nos vê regidos por um volume de capital financeiro, do qual apenas um por cento atua produtivamente. Os que especulam com isso e comandam a situação não foram escolhidos por nós e são até inexpressivos.

Por trás disso, "como segundo círculo desse inferno moderno ou pósmoderno, agem os manipuladores dos grandes meios de comunicação de massa". Somente então aparecem os políticos; seu poder parece fictício, mera fachada. (Tal é o relato de Jorge Edwards, escritor chileno, em El País, de 21.7.98, p. 10: "La palabra sospechosa".) Essa percepçáo do mundo global e capitalista ao final do século XX é representativa para inúmeros contemporâneos. $\mathrm{O}$ que mais ela representa além da proletarização da enorme parte da populaçáo mundial, seja ela feita de white ou blue-collars, e a despeito da diferença formal entre trabalho independente e dependente? Ainda que o Manifesto induza ao erro, onde prognostica a redução de todas as classes "em dois grandes campos inimigos, em duas grandes classes diretamente confrontadas: burguesia e proletariado", não se deve ignorar a idéia de que, na relação com as potências que dominam o mundo, exploram a economia e governam sem mandato legítimo, a maior parte da populaçáo mundial encontra-se praticamente proletarizada: politicamente sem capacidade de ação e economicamente talvez com uma participação secundária. 
Naturalmente isso é apenas um quase proletariado. Suas múltiplas cisóes em interesses parciais impedem sua representaçáo política uniforme. Todavia, talvez esse pensamento seja útil para manter viva a provocaçáo produtiva do Manifesto. Pois nada é mais fatal para o espírito do que caminhar sem reservas com o espírito do tempo. O tempo é breve com seu próprio espírito. Cronos devora seus filhos. Na próxima virada da história, todos aguardam o inesperado. Apesar de a (pre)visão do Manifesto a respeito da globalização e do desenvolvimento da técnica se confirmar, hoje o espírito do tempo parece ultrapassado em sua principal suposição dialética: na verdade, parte-se do caráter contraditório do desenvolvimento e, portanto, do fato de que nem as forças produtivas nem as respectivas relaçóes e situaçóes mundiais expressam uma condiçáo homogênea. Todo fenômeno é transitório e atravessado por forças em conflito, cujas resultantes podem até constituí-lo.

Hoje, sob a dupla impressão do pós-comunismo e da crise ecológica, seria possível estabelecer, sobretudo entre os esquerdistas, um amplo consenso de que essa suposiçáo dialética tenha se tornado antiquada: antigamente as coisas eram contraditórias, porém tornaram-se inequívocas. É preciso ser contra a globalização e a tecnologia de ponta. No entanto, justamente agora que sobretudo seus adeptos o abandonam, $o$ Manifesto poderia se revelar completamente atual. Sendo assim, a luta não seria contra a globalização e as forças produtivas, mas por elas.

Wolfgang Fritz Haug é professor da Universidade Livre de Berlim, Alemanha.

Tradução de Karina Jannini. O original em alemão - Unzeitgemässe Betrachtungen zum Kommunistischen Manifest - encontra-se à disposiçáo do leitor no IEA-USP para eventual consulta. 